\title{
Effect of material and technological factors on the properties of cement-lime mortars and mortars with plasticizing admixture
}

https://doi.org/10.1515/eng-2019-0005

Received Apr 20, 2018; accepted Oct 03, 2018

\section{Introduction}

Lime is a commonly used constituent of cement-based mortars and plasters used in masonry. Lime improves consistency and workability of the fresh mortars [1, 11], while improving the stability of the fresh mortar in relation to its water retention $[10,15,16]$. Hardened cement-lime mortars also exhibit lower compressive strength and slightly higher flexural strength, what in turn makes the mortars weaker but more deformable, what is a desired trait for masonry [6-8].

In Polish construction practice, lime has been mainly perceived and treated as a plasticizing agent. Therefore, when plasticizing admixtures for masonry mortars and plasters were introduced, they were often regarded as a direct substitute for lime, and this trend is still present in the current Polish construction practice [14]. The perception of plasticizing admixtures as direct substitutes for lime leads to a common belief that their effect on the properties of fresh masonry mortars and plasters is also comparable [9]. This can cause problems during construction process, especially taking under consideration the non-stable conditions of making and applying plaster and masonry mortar on the construction site. While the difference of the properties of mortars and plasters has been a subject of comparative studies such as [17], the research into topic of the effect of material and technological factors on the properties of cement-lime mortars and mortars with plasticizing admixture yields little results.

\footnotetext{
*Corresponding Author: Małgorzata Gołaszewska: Department of Civil Engineering, Silesian University of Technology, Poland; Email: malgorzata.golaszewska@polsl.pl Jacek Gołaszewski, Grzegorz Cygan: Department of Civil Engineering, Silesian University of Technology, Poland
}

The aim of the research was to compare the sensitivity of the fresh cement-lime mortars and fresh mortars with admixture to chosen missteps that can occur on the construction site during mixing, to preliminarily ascertain viability and utility of using the admixture as a direct substitute for lime, as it is usually treated in practice.

This paper presents results from experimental research into the effect of material and technological factors on the properties of cement-lime mortars and mortars with air-entraining plasticizing admixture which was marketed and commonly used as a direct substitute of lime. Study consisted of tests of consistency and air content, performed with the regard to possible dosing mistakes for lime/plasticizer and water, and changes in mixing conditions, namely temperature of the mortar and mixing intensity.

\section{Experimental details}

For the research, following materials were used: cement CEM I $42.5 \mathrm{R}$, two types of lime from different producers, one plasticizing admixture based on naphthalene resin, standard sand according to EN 196-1 [5].

Mortars with a volume ratio of cement, lime and sand 1: 1: 6 were made as plasters and masonry mortars. For plaster, a consistency equal to $9 \mathrm{~cm}$ to Novikov's cone [12] was assumed, for masonry mortar $-7 \mathrm{~cm}$. The amount of water was experimentally adjusted to obtain these consistencies. The volume ratio of cement to sand of mortars with plasticizing admixture was $1: 6$, the admixture content was assumed as $0.25 \%$ of the cement mass. The amount of water was adjusted for consistency similarly to cement-lime mortar.

The exact compositions and assumed designation of mortars and plasters is shown in Table 1.

Several factors that could influence the properties of the mortars and plasters were chosen. The factors were chosen based on the most common and probable deviations from the standard conditions on the construction

OOpen Access. (C 2019 J. Gołaszewski et al., published by De Gruyter. (cc) BY 4.0 License 
Table 1: Compositions of the plaster mortars for $1 \mathrm{~m}^{3}$.

\begin{tabular}{|c|c|c|c|c|c|c|}
\hline Component[kg] Mortar & Z1T & Z2T & Z3T & Z1M & $\mathrm{Z2M}$ & $\mathrm{Z3M}$ \\
\hline CEM I 42.5 R & 169 & 186 & 184 & 177 & 189 & 189 \\
\hline Plasticizing admixture & 0.426 & & & 0.446 & & \\
\hline Lime "N" & & 89 & & & 91 & \\
\hline Lime "T" & & & 88 & & & 91 \\
\hline Sand & 1455 & 1599 & 1582 & 1525 & 1625 & 1625 \\
\hline Water & 197 & 284 & 287 & 189 & 271 & 274 \\
\hline
\end{tabular}

Table 2: The research plan.

\begin{tabular}{|c|c|c|c|}
\hline Factor & Changeability & Plaster & Masonry mortar \\
\hline $\begin{array}{l}\text { Temperature of the } \\
\text { mortar/plaster }\end{array}$ & $+5^{\circ} \mathrm{C} ;+20^{\circ} \mathrm{C} ;+35^{\circ} \mathrm{C}$ & $\begin{array}{l}\text { Plasticizing admixture } \\
\text { Lime (2 types) }\end{array}$ & $\begin{array}{l}\text { Plasticizing admixture } \\
\text { Lime (2 types) }\end{array}$ \\
\hline Mixing intensity & Low, standard, high & $\begin{array}{l}\text { Plasticizing admixture } \\
\text { Lime (2 types) }\end{array}$ & $\begin{array}{l}\text { Plasticizing admixture } \\
\text { Lime (2 types) }\end{array}$ \\
\hline \multicolumn{4}{|c|}{ Dosing mistakes } \\
\hline $\begin{array}{l}\text { Amount of lime } \\
\text { /admixture }\end{array}$ & $\pm 10 \%$ of mass & $\begin{array}{l}\text { Plasticizing admixture } \\
\text { Lime (2 types) }\end{array}$ & $\begin{array}{l}\text { Plasticizing admixture } \\
\text { Lime (2 types) }\end{array}$ \\
\hline Amount of water & $\pm 10 \%$ of mass & $\begin{array}{l}\text { Plasticizing admixture } \\
\text { Lime ( } 2 \text { types) }\end{array}$ & $\begin{array}{l}\text { Plasticizing admixture } \\
\text { Lime (2 types) }\end{array}$ \\
\hline
\end{tabular}

sites. The temperature on the construction site is usually different from $+20^{\circ} \mathrm{C}$ leading to differences in mortar temperature, the mixing time can vary, and small dosing mistakes can occur. The changes in those factors were tested in order to ascertain how the changes of those factors influence the properties of the fresh mortar. The full research plan is shown in Table 2.

\subsection{Methodology}

To determine the effect of the changeability of the tested factors, following tests were performed:

- consistency determined by the Novikov's cone method according to PN-B-04500 [12],

- consistency determined by the plunger penetration method according to EN 1015-4:2000 [3],

- Fluidity determined by the cement flow table method according to EN 1015-3: 2000 [2],

- air content in the mortar according to EN 1015-7 [4],

All the procedures were conducted in laboratory conditions and in accordance to the standards, except for tests of set conditions (temperature, mixing time).

The changed mortar and plaster temperature was obtained by placing measured materials in the freezer (for $+5^{\circ} \mathrm{C}$ mortars) or climatic chamber (for $+35^{\circ} \mathrm{C}$ mortars) for $24 \mathrm{~h}$. The temperatures in freezer and climatic chamber were experimentally adjusted, in order to obtain the mortar of set temperature after mixing. The temperature of the mortar was monitored immediately after mixing, and before each test.

Basic mixing intensity was set according to EN 1961 [5]. Slow mixing intensity was set as $90 \mathrm{rpm}$ for $3 \mathrm{~min}$, while high mixing intensity was $140 \mathrm{rpm}$ for $3 \mathrm{~min}$.

Changes in dosage were calculated by mass of the constituent, as it is the most probable mistake that can be made on the construction site.

The sensitivity of the properties of mortars to changes of the set factors was calculated according to following formula:

$$
W=\frac{S}{\bar{x}} \times 100 \%
$$

Where $W$ - sensitivity of a factor [\%], $s$ - standard deviation of the measurements of a given property for all set cases for a factor, $\bar{x}$ - mean of all the measurements of a given property. 
Table 3: Results of the tests for plaster and mortars in three temperatures: $+20^{\circ} \mathrm{C},+5^{\circ} \mathrm{C}$, and $+30^{\circ} \mathrm{C}$.

\begin{tabular}{|c|c|c|c|c|c|c|}
\hline \multirow{2}{*}{ Property $\quad$ Mortar type } & \multicolumn{3}{|c|}{ Plaster } & \multicolumn{3}{|c|}{ Masonry mortar } \\
\hline & Z1T & Z2T & Z3T & Z1M & Z2M & Z3M \\
\hline \multicolumn{7}{|c|}{ Temperature $+20^{\circ} \mathrm{C}$} \\
\hline Flow diameter $[\mathrm{mm}]$ & 192 & 222 & 216 & 159 & 201 & 201 \\
\hline Cone penetration $[\mathrm{cm}]$ & 8.9 & 9.5 & 8.9 & 6.4 & 7.4 & 6.9 \\
\hline Plunger penetration [mm] & 28 & 35 & 36 & 19 & 23 & 26 \\
\hline Air content [\%] & 18.8 & 2.4 & 2.8 & 17 & 3.2 & 3.4 \\
\hline \multicolumn{7}{|c|}{ Temperature $+5^{\circ} \mathrm{C}$} \\
\hline Flow diameter [mm] & 198 & 227 & 213 & 181 & 218 & 209 \\
\hline Cone penetration $[\mathrm{cm}]$ & 9.9 & 10.5 & 9.9 & 7.3 & 9.6 & 7.6 \\
\hline Plunger penetration [mm] & 39 & 44 & 41 & 23 & 30 & 28 \\
\hline Air content [\%] & 19.4 & 2.2 & 3.0 & 19.5 & 4.9 & 3.7 \\
\hline \multicolumn{7}{|c|}{ Temperature $+35^{\circ} \mathrm{C}$} \\
\hline Flow diameter [mm] & 182 & 219 & 226 & 173 & 210 & 206 \\
\hline Cone penetration $[\mathrm{cm}]$ & 8.3 & 9.6 & 10 & 7 & 8.1 & 7.9 \\
\hline Plunger penetration [mm] & 29 & 40 & 43 & 20 & 31 & 29 \\
\hline Air content [\%] & 19 & 2.5 & 4.0 & 18.5 & 4.2 & 4.4 \\
\hline
\end{tabular}

\section{Results}

\subsection{The influence of temperature on the properties of mortars and plasters}

Mortars and plasters were tested at temperature of $+5,+20$ and $+35^{\circ} \mathrm{C}$. The results of the tests are shown in Table 3 .

The sensitivity of plasters and mortars to temperature, calculated according to formula 1, is shown in Figure 1.

Generally, plasters with plasticizing admixture show greater sensitivity of consistency to temperature changes from cement-lime mortars, in the case of masonry mortars the sensitivity is similar or smaller.

The mechanism of lower sensitivity of cement-lime mortars in lower and higher temperatures can be explained by the fact that $+5^{\circ} \mathrm{C}$ and $+35^{\circ} \mathrm{C}$ are the borderline values for the effective use of the admixture, and thus the plasticizing agents effect of the admixture can be already diminished, leaving just the air-entraining effect, which is just a part of plasticizing effect of the admixture.

In case of masonry mortars, the Z2M cement-lime mortar exhibits greater sensitivity to temperature changes than the mortars with admixtures. It must be noted that masonry mortars have a lower amount of water, and therefore are more susceptible to changes in water retention of mortar, which changes together with temperature.

The cement-lime mortars exhibit higher sensitivity to changes of temperature in case of air content in mortar, however it is mostly due to the fact that the air content in

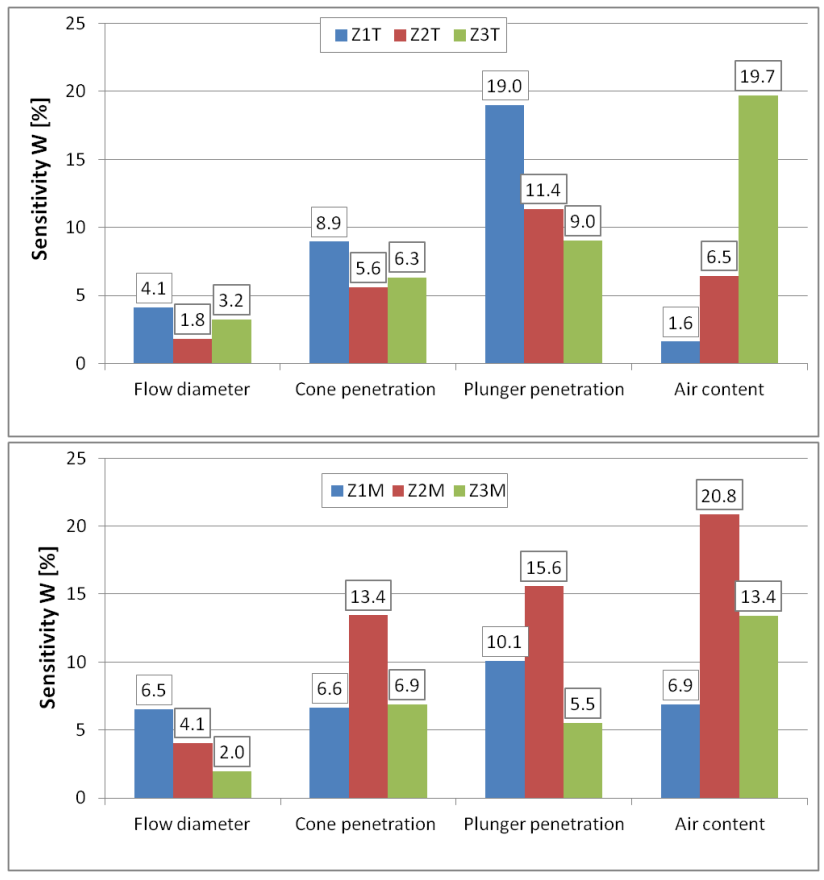

Figure 1: The sensitivity of the properties of plasters (top) and mortars (bottom) to changes in temperature.

cement-lime mortars is lower by the order of magnitude from the air content in mortar with the admixture, and even small changes are high in percentage. 
Table 4: Results of the tests of plaster and mortars mixed by 3 different intensities of mixing procedure.

\begin{tabular}{|c|c|c|c|c|c|c|}
\hline \multirow{2}{*}{ Property } & \multicolumn{3}{|c|}{ Plaster } & \multicolumn{3}{|c|}{ Masonry mortar } \\
\hline & Z1T & Z2T & Z3T & Z1M & Z2M & Z3M \\
\hline \multicolumn{7}{|c|}{ Standard mixing } \\
\hline Flow diameter [mm] & 192 & 222 & 216 & 159 & 201 & 201 \\
\hline Cone penetration $[\mathrm{cm}]$ & 8.9 & 9.5 & 8.9 & 6.4 & 7.4 & 6.9 \\
\hline Plunger penetration [mm] & 28 & 35 & 36 & 19 & 23 & 26 \\
\hline Air content [\%] & 18.8 & 2.4 & 2.8 & 17 & 3.2 & 3.4 \\
\hline \multicolumn{7}{|c|}{ Fast mixing } \\
\hline Flow diameter [mm] & 205 & 228 & 216 & 180 & 201 & 198 \\
\hline Cone penetration $[\mathrm{cm}]$ & 9.0 & 10.3 & 8.9 & 6.5 & 9.9 & 7.2 \\
\hline Plunger penetration [mm] & 29 & 40 & 31 & 20 & 30 & 23 \\
\hline Air content [\%] & 18.0 & 2.0 & 3.0 & 17.0 & 3.1 & 3.8 \\
\hline \multicolumn{7}{|c|}{ Slow mixing } \\
\hline Flow diameter [mm] & 196 & 223 & 227 & 177 & 212 & 207 \\
\hline Cone penetration $[\mathrm{cm}]$ & 9 & 8,8 & 9.3 & 6.5 & 8.1 & 8 \\
\hline Plunger penetration [mm] & 26 & 32 & 30 & 23 & 36 & 26 \\
\hline Air content [\%] & 19.5 & 2.3 & 3.6 & 19 & 3.3 & 3.9 \\
\hline
\end{tabular}

\subsection{The influence of mixing intensity changes on the properties of mortars and plasters}

The results of the tests are shown in Table 4.

The sensitivity of plasters and mortars to mixing intensity, calculated according to formula 1 is shown in Figure 2.

Plasters and masonry mortars with admixture were found to be mostly non-sensitive to differing mixing speed. With regard to consistency measured by cone penetration and plunger penetration, cement-lime mortars and plasters were found to be generally more sensitive to changes in the mixing procedure than cement mortars with plasticizing admixture, however the sensitivity is not visible in case of flow diameter test. This might be due to the fact that cone penetration and plunger penetration is partially dependant on viscosity of the fresh mortar, while flow diameter can be linked to its yield stress [13]. Different speed of mixing can influence the viscosity of the cement-lime mortars to a greater degree than in case of mortars with admixture, as the high air content in mortars with admixture is one of the most important factors that shape the rheological properties of the fresh mortar, and it was practically not affected by the different mixing speeds.

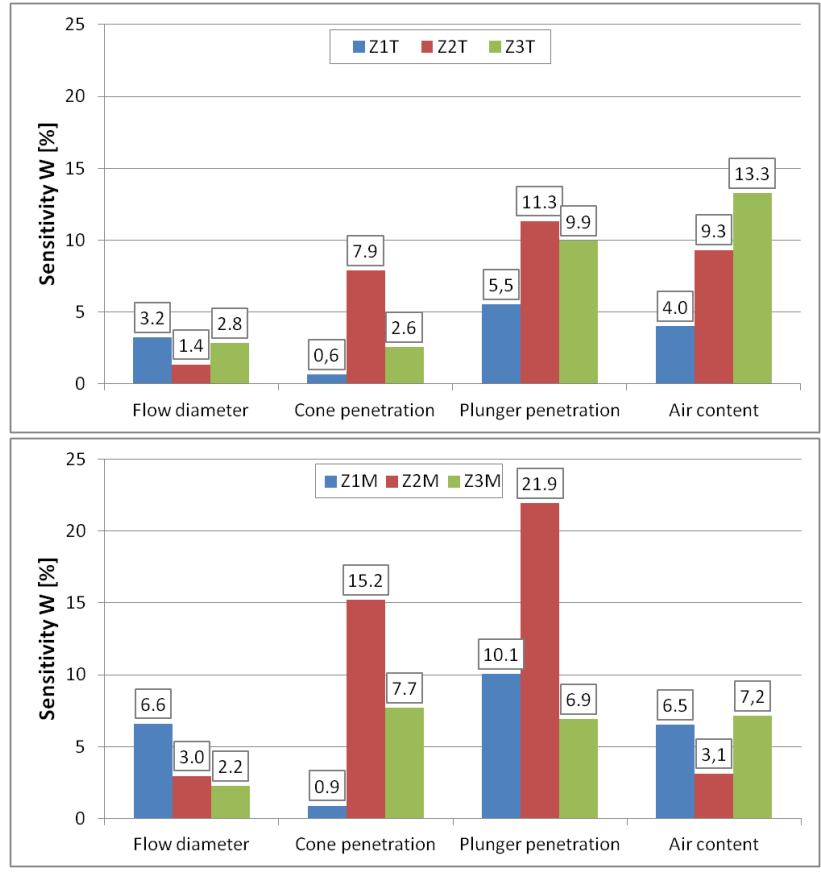

Figure 2: The sensitivity of the properties of plasters (top) and mortars (bottom) to different mixing speeds.

\subsection{The influence of dosing mistakes on the properties of mortars and plasters}

Inaccuracies in the process of adding the right amount of water to the mortar are considered to be common on the construction site due to e.g. the lack of accurate measuring equipment on the site. Due to this fact, in the paper, a 
Table 5: Results of the tests of plaster and mortars with $10 \%$ fluctuations of water content.

\begin{tabular}{|c|c|c|c|c|c|c|}
\hline \multirow[t]{2}{*}{ Mortar type } & \multicolumn{3}{|c|}{ Plaster } & \multicolumn{3}{|c|}{ Masonry mortar } \\
\hline & Z1T & $\mathrm{Z2T}$ & Z3T & Z1M & Z2M & Z3M \\
\hline \multicolumn{7}{|c|}{ Regular amount of water } \\
\hline Flow diameter [mm] & 192 & 222 & 216 & 159 & 201 & 201 \\
\hline Cone penetration $[\mathrm{cm}]$ & 8.9 & 9.5 & 8.9 & 6.4 & 7.4 & 6.9 \\
\hline Plunger penetration [mm] & 28 & 35 & 36 & 19 & 23 & 26 \\
\hline Air content [\%] & 18.8 & 2.4 & 2.8 & 17 & 3.2 & 3.4 \\
\hline \multicolumn{7}{|c|}{$+10 \%$ of water } \\
\hline Flow diameter [mm] & 262 & 251 & 230 & 210 & 239 & 237 \\
\hline Cone penetration [cm] & 12.2 & 11.2 & 11.1 & 9.7 & 10.5 & 9.3 \\
\hline Plunger penetration [mm] & 50 & 46 & 40 & 35 & 36 & 33 \\
\hline Air content [\%] & 21.0 & 1.2 & 2.5 & 19.2 & 2,0 & 2.1 \\
\hline \multicolumn{7}{|c|}{$-10 \%$ of water } \\
\hline Flow diameter [mm] & 164 & 196 & 197 & 144 & 173 & 177 \\
\hline Cone penetration $[\mathrm{cm}]$ & 6 & 6,8 & 6,7 & 4,9 & 5,1 & 4,8 \\
\hline Plunger penetration [mm] & 17 & 18 & 15 & 12 & 14 & 12 \\
\hline Air content [\%] & 15.5 & 4.2 & 3.3 & 14 & 4.5 & 3.6 \\
\hline
\end{tabular}

measured was the sensitivity of the mortars and plasters to the small changes in water content $( \pm 10 \%$ of water mass).

The results of the tests are shown in Table 5.

The sensitivity of plasters and mortars to changes in water dosage, calculated according to formula 1 , are shown in Figure 3.

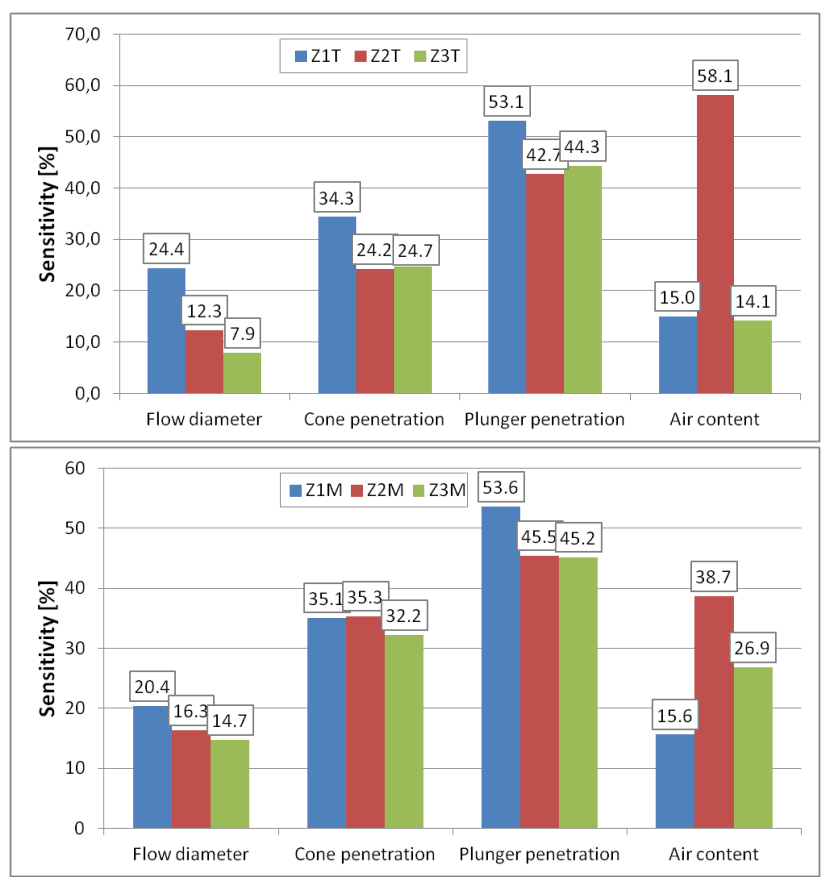

Figure 3: The sensitivity of the properties of plasters (top) and mortars (bottom) to $\pm 10 \%$ mistake of water dosage.
Mistakes in dosing water for the mortar have the predictable effect - worsening of the consistency in the case when there was less water added, increase of the fluidity in the case of overdosing the water. The consistency of mortars and pastes changes significantly as a result of changes in the amount of water, and mortars with plasticizing admixture show greater sensitivity than lime-cement mortars.

This is most probably due to the fact that the plasticizing admixture grants the desired consistency mostly by its aerating effect. Due to the fact that the degree of aeration of the mortar depends on the amount of water, smaller amount of water contributes to the smaller air content, and, in addition to reducing the amount of water, additionally contributes to the lower consistency in mortars with plasticizing admixture. The opposite effect takes place in case of the overdose of water, what results in increased fluidity, what explains slightly higher sensitivity of mortars and plasters with plasticizing admixture.

Similarly to water, problems and mistakes may occur while dosing the plasticizing admixture or lime itself to mortar. A mistake on the level of $\pm 10 \%$ of the mass of plasticizing admixture or lime was assumed.

Results of the test are shown in Table 6.

The sensitivity of plasters and mortars to changes in water dosage, calculated according to formula 1 , are shown in Figure 4.

The sensitivity of cement-lime plaster and cement plaster with plasticizing admixture to changes in the amount of, respectively, lime and admixture is similar, 
Table 6: Results of the tests of plaster and mortars with $10 \%$ changes of admixture/lime content.

\begin{tabular}{|c|c|c|c|c|c|c|}
\hline \multirow{2}{*}{ Property Mortar type } & \multicolumn{3}{|c|}{ Plaster } & \multicolumn{3}{|c|}{ Masonry mortar } \\
\hline & Z1T & $\mathrm{Z2T}$ & Z3T & Z1M & Z2M & Z3M \\
\hline \multicolumn{7}{|c|}{ Regular amount of admixture/lime } \\
\hline Flow diameter [mm] & 192 & 222 & 216 & 159 & 201 & 201 \\
\hline Cone penetration $[\mathrm{cm}]$ & 8.9 & 9.5 & 8.9 & 6.4 & 7.4 & 6.9 \\
\hline Plunger penetration [mm] & 28 & 35 & 36 & 19 & 23 & 26 \\
\hline Air content [\%] & 18.8 & 2.4 & 2.8 & 17 & 3.2 & 3.4 \\
\hline \multicolumn{7}{|c|}{$+10 \%$ of admixture/lime } \\
\hline Flow diameter [mm] & 200 & 223 & 222 & 178 & 202 & 199 \\
\hline Cone penetration $[\mathrm{cm}]$ & 9.1 & 9.5 & 8.9 & 7.0 & 7.0 & 6.6 \\
\hline Plunger penetration [mm] & 47 & 29 & 36 & 24 & 19 & 20 \\
\hline Air content [\%] & 19.0 & 2.3 & 2.0 & 19.8 & 3.7 & 2.8 \\
\hline \multicolumn{7}{|c|}{$-10 \%$ of admixture/lime } \\
\hline Flow diameter [mm] & 186 & 228 & 226 & 145 & 204 & 207 \\
\hline Cone penetration $[\mathrm{cm}]$ & 8.2 & 9.1 & 9.4 & 5.9 & 7.5 & 7.2 \\
\hline Plunger penetration [mm] & 22 & 25 & 35 & 17 & 27 & 28 \\
\hline Air content [\%] & 18.5 & 3.3 & 2.8 & 16 & 3.7 & 3.4 \\
\hline
\end{tabular}

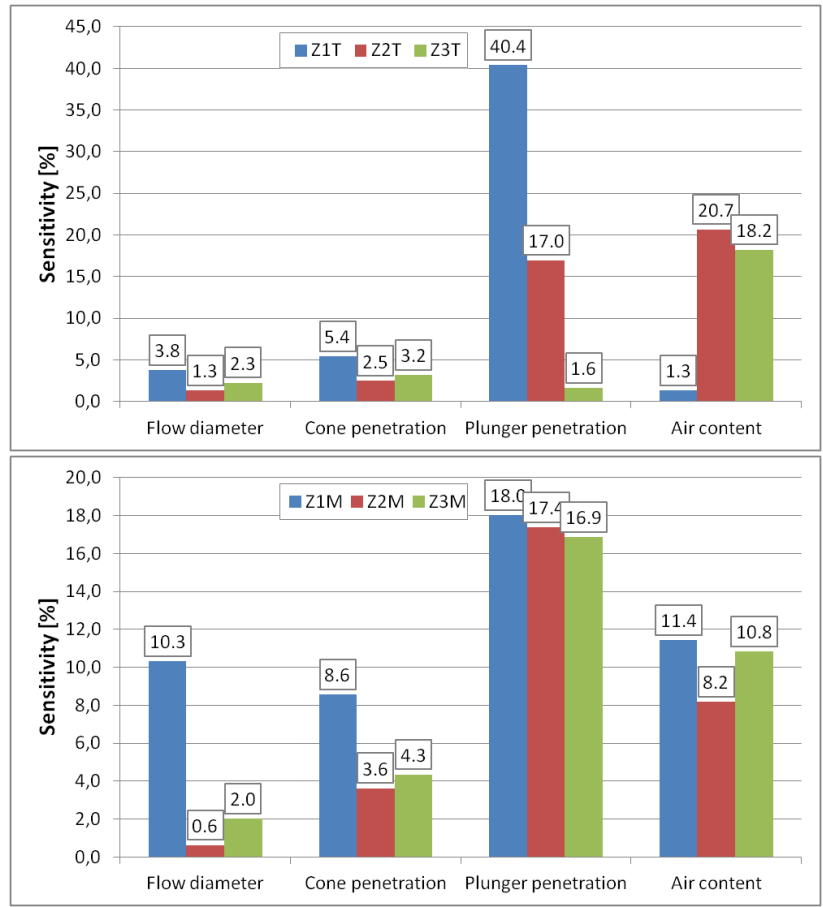

Figure 4: The sensitivity of the properties of plasters (top) and mortars (bottom) to $\pm 10 \%$ mistake of admixture/lime dosage.

only in case of plunger penetration, mortar with admixture is extremely more sensitive to changes in admixture amount. In the case of masonry mortars, mortars with plasticizing admixture are more sensitive to changes in the amount of admixture in terms of consistency than cementlime mortars to changes in lime amount. This effect can be contributed to the difference in the absolute amount of both constituents. To obtain similar consistencies, much less plasticizer is needed, and thus even is the general percent of the change is the same, it is relatively detrimental in the case of admixture.

Cement mortars with tested plasticizing admixture may have similar or less resistance to mistakes in adding admixture than cement-lime mortars for errors in the dosage of lime.

\section{Conclusions}

The research leads to following conclusions:

- masonry mortars and plasters with chosen plasticizing admixture exhibit greater sensitivity of the properties of on errors in dosing than lime-cement mortars and pastes. This applies to both consistency, and air content.

However, with regard to the consistency, it should be noted that changeability of cement mortars and plasters with plasticizing admixture measured by cone penetration does not exceed $15 \%$, when expressed in absolute values in the case of plasters and masonry mortars is \pm 0.7 and $\pm 0.5 \mathrm{~cm}$ respectively, what can be considered to be within the limits of acceptable error.

- Cement-lime mortars show similar or greater sensitivity to changed temperature. This might be ex- 
plained by the fact that cement-lime mortars have higher water content, and thus adverse effects of temperature which are linked with water content are more visible.

- Cement-lime mortars show similar or greater sensitivity to different mixing intensity. This might be linked to the changes in viscosity due to differing mixing intensity, what is lesser important in case of mortars with admixture due to its high aeration.

In conclusion, the conducted research indicates that in practical use, the cement-lime mortars and mortars with the plasticizing admixture should not be treated as direct substitutes. The technological and material requirements differ, and preparations of mortars with plasticizing admixture should be given different considerations than those of cement-lime mortars.

\section{References}

[1] Boyton R.S.: The Chemistry and Technology of Lime and Limestone. New York 1996

[2] EN 1015-3: 2000, Methods of test for mortar for masonry. Determination of consistence of fresh mortar (by flow table)

[3] EN 1015-4: 2000, Methods of test for mortar for masonry. Determination of consistence of fresh mortar (by plunger penetration)

[4] EN 1015-7, Methods of test for mortar for masonry. Determination of air content of fresh mortar

[5] EN 196-1:2016 Methods of testing cement. Determination of strength

[6] Fourmentin, M., Faure, P., Gauffinet, S., Peter, U., Lesueur, D., Daviller, D., Coussot, P. Porous structure and mechanical strength of cement-lime pastes during setting. Cement and Concrete Research, 2015, 77, 1-8.
[7] Green, K. M., Carter, M. A., Hoff, W. D., \& Wilson, M. A. The effects of lime and admixtures on the water-retaining properties of cement mortars. Cement and Concrete Research, 1999, 29(11), 1743-1747.

[8] Katzer, J., \& Kobaka, J. Assessing the Strength of Gothic Brickwork / Bestimmung der Festigkeit von gotischem Mauerwerk. Restoration of Buildings and Monuments, 2007,13(4), 265-276.

[9] Lenart, M. Impact Assessment of Lime Additive and Chemical Admixtures on Selected Properties of Mortars. Procedia Engineering, 2013, 57, 687-696.

[10] Nogueira, R., Ferreira Pinto, A. P., \& Gomes, A. Design and behavior of traditional lime-based plasters and renders. Review and critical appraisal of strengths and weaknesses. Cement and Concrete Composites, 2018, 89, 192-204.

[11] O‘Looney, D., \& Pavía, S. A Study of the Functionality of Hydrated Lime as an Admixture. Journal of Materials Science Research, 2014, 4(1).

[12] PN-B-04500 :1985 Building mortars - Physical properties and strength tests (in Polish)

[13] Roussel N, Stefani C, Leroy R. From Mini-Cone Test to Abrams Cone Test: Measurement of Cement-Based Materials Yield Stress Using Slump Tests. Cement and Concrete Research, 2005, 35(5), 817-822

[14] Schuller, M., van der Hoeven, R., Thomson, M. Comparative Investigation of Plastic Properties and Water Permeance of Cement-Lime Mortars and Cement-Lime Replacement Mortars. Water Problems in Building Exterior Walls: Evaluation, Prevention, and Repair, ed. Boyd JM, Scheffler MJ, 1999.

[15] Seabra, M. P., Labrincha, J. A., \& Ferreira, V. M. Rheological behaviour of hydraulic lime-based mortars. Journal of the European Ceramic Society, 2007. 27(2-3), 1735-1741.

[16] Seabra, M. P., Paiva, H., Labrincha, J. A., \& Ferreira, V. M. Admixtures effect on fresh state properties of aerial lime based mortars. Construction and Building Materials, 2009, 23(2), 11471153.

[17] Walker P.,. Kioy S, Amy J. An experimental comparison of hydrated lime and an admixture for masonry mortars, International Masonry Conference 2014, 1-9. 